\title{
AGE AND SEDIMENTOLOGICAL FEATURES OF FLUVIAL SERIES IN THE TORUŃ BASIN AND THE DRWECA VALLEY (POLAND)
}

\author{
PIOTR WECKWERTH ${ }^{1}$, KRZYSZTOF PRZEGIETKA ${ }^{2}$, ALICJA CHRUŚCIŃSKA ${ }^{2}$, \\ BARBARA WORONKO ${ }^{3}$ and HUBERT L. OCZKOWSKI ${ }^{2}$ \\ ${ }^{1}$ Institute of Geography, Nicolaus Copernicus University, Gagarina 9, 87-100 Toruń, Poland \\ ${ }^{2}$ Institute of Physics, Nicolaus Copernicus University, Grudziadzka 5/7, 87-100 Toruń, Poland \\ ${ }^{3}$ Faculty of Geography and Regional Studies, University of Warsaw, Krakowskie Przedmieście 30, 00-927 Warszawa, Poland
}

Received 26 May 2010

Accepted 28 March 2011

\begin{abstract}
The deposits of the Torun Basin are dominated by a few-metre thick sand series which fill up buried valley-like depressions. In many cases they underlie the Weichselian till which builds up the ice marginal streamway (pradolina) terraces or they are exposed at the basin slopes. As the results of the geological and sedimentological studies, as well as of the dating of the deposits at the sites in the Torun Basin indicate, the deposits include two fluvial series accumulated before the advancement of the Leszno Phase ice sheet, i.e. in Middle Weichselian and at the beginning of Late Weichselian. The oldest fluvial series connected with the Saalian Glaciation was found at the mouth section of the Drwęca Valley. The fluvial system of the Torun Basin during Middle Weichselian and at the beginning of Late Weichselian developed in two phases of the sand-bed braided river. During the first one the river channel were dominated by large mid-riverbed sandbars, while during the second phase the water flow was smaller and, as a result, low transverse sandbars and two-dimensional dunes developed. Other active river channel also showed low-energy flows, more intensive meandering than in the case of the braided rivers, as well as sandy side-bars. Analysis of the rounding and frosting of the quartz grains indicate that the studied series of the Weichselian sandy deposits represent alluvia of a river which were fed from two diverse sources. The first one might have represented the alluvia of a warm river which transformed its load, while the other one might have mainly carried the underlying Quaternary deposits.
\end{abstract}

Keywords: Weichselian Glaciations, sand-bed braided river, sinuous channel, Toruń Basin, OSL dating, frosting and rounding analysis of quartz grains.

\section{INTRODUCTION}

Fluvial series deposited in the Torun Basin at the time when it was free from ice sheet intersected one another and used the earlier valley forms which had not been totally levelled by either glacial accumulation or erosion. The series of sandy and sandy-gravel deposits, which dominate in the geological structure of the western and the south-western part of the Torun Basin, fill up buried

Corresponding author: P. Weckwerth

e-mail: pweck@umk.pl valleys the bottoms of which contact the top of the Neogene deposits (Weckwerth, 2007; 2010). The main lowering of the buried valley follows here the basin's axis. The Pleistocene fluvial series which fill up the western and south-western part of the Torun Basin end up the Weichselian accumulation of sands or sands and silts (Włodek, 1980; Wysota, 2002). These deposits are common in the Torun Basin which, according to Włodek (1980), is crucial for stratigraphic recognition of Weichselian. In accordance with the research results of Wysota et al. (1996) and Wysota (2002) on the neighbouring Chełmno Plateau 
to the north, these deposits can be related to the interstadial deposits of the Rzęczkowo formation of Middle Weichselian. Moreover, the investigations carried out by Molewski (2007) indicate that their later deposition, i.e. in Late Weichselian shortly before the Leszno Phase ice sheet advance, needs to be considered.

The referred fluvial series deposited before the Leszno Phase are exposed in numerous settings located in the central and western part of the Torun Basin and are found under the sandy-gravel deposits of the pradolina terraces or beneath the till layers. As the results of the studies carried out so far on the fluvial series in two research sites in the Torun Basin indicate, their deposits were accumulated by braided rivers (Weckwerth, 2009a; 2009b). The deposits of these rivers differ in terms of their age and they show diverse shaping of riverbed forms and thus they had different energy of the depositional environment which depended on the advance and retreat of ice sheet. Due to this the development of river systems which exhibit braiding diversity and both braided and meandering or anabranching patterns (Olsen, 1988; Marren, 2005; Salamon and Zieliński, 2010).

The results of the studies presented in this article, together with the analysis of the development of the fluvial series within the following research sites located in the Torun Basin and in the lower section of the Drwęca Valley (Fig. 1), make it possible to characterize the palaeoenvironment of fluvial accumulation of the deposits underlying the till on the pradolina terraces, as well as to assess their age.

\section{RESEARCH METHODS}

The reconstruction of the depositional environment in the research sites in question was based on the structural and textural features of the deposits. Genetic classification of the deposits, the types of lithofacies, as well as characteristics of the individual lithofacies and the contact between them in order to delimit sedimentary units characteristic for the environment and fluvial subenvironment were established in exposures (Miall, 1985; Zieliński, 1993; 1998). The lithofacial analysis was based on the lithofacial code (Miall, 1978; Zielinnski, 1998). The reconstruction of the directions of palaeocurrents was based on the orientation of the cross-stratification presented on rose diagrams, where: $\mathrm{N}$ - population, VM vector mean $\left({ }^{\circ}\right), \mathrm{CI}$ - confidence interval, $\mathrm{SD}$ - standard deviation and $\mathrm{R}$ - clustered data ratio (\%) (Figs. 8, 9, 11). The grain size distribution of gravel-sand fraction in interval of 1 phi was determined by the sieve method and for sand-clay fraction was measured with laser particle size analyser (Analysette 22) in interval 0.25 phi. The analysis of the distribution of the size composition of the deposits enabled the authors to determine the median grain diameter $d_{50}$ as well as their statistical parameters using the method of Folk and Ward (1957) graphical measures, i.e. GSS - average grain diameter, GSO -
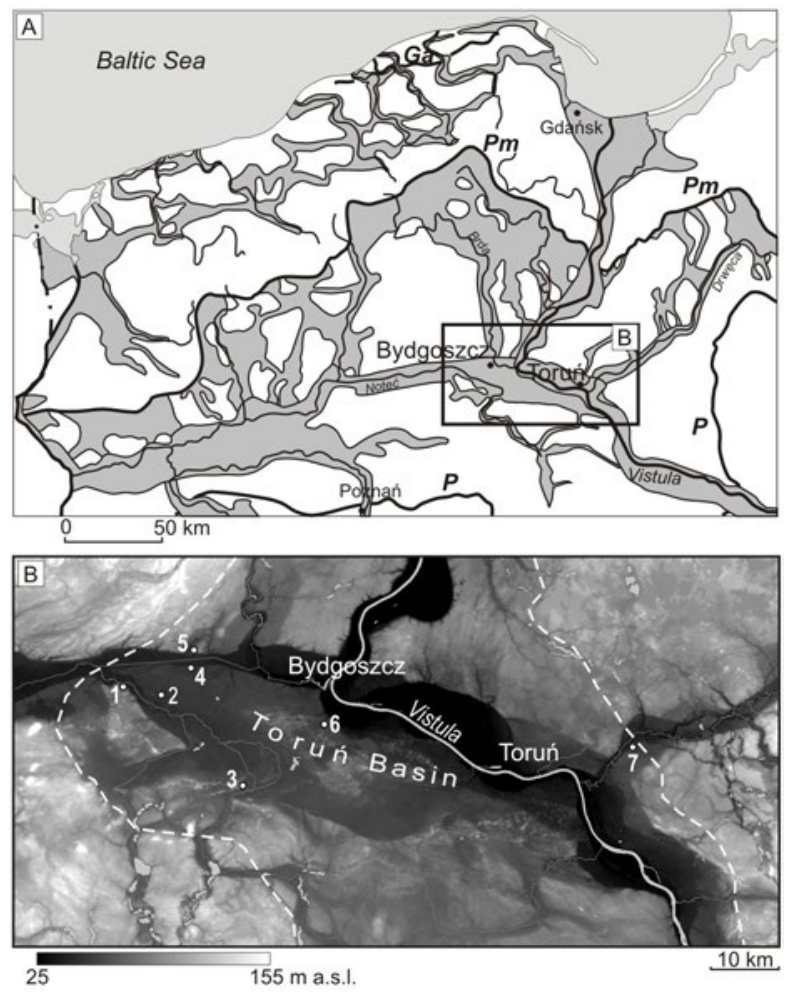

Fig. 1. Location of study area $(A)$ and analysed sites in the Torun Basin and in the mouth section of the Drwęca Valley (B). A: maximum extent of Poznań Phase (P), Pomeranian Phase (Pm), Gardno Phase (Ga); B: sites: 1 - Chobielin, 2 - Tur, 3 - Nowe Dąbie, 4 - Łochowo, 5 - Zielonczyn, 6 - Wypaleniska, 7 - Młyniec; white dashed line presumable range of exaration depression (according to Molewski, 2007).

standard deviation, GSK - skewness, and GSP - kurtosis. These statistical parameters were assisting in the lithofacial analysis. The studies of the tills in the selected profiles included the analysis of their grain size, the measurement of the longer axes of the clasts (population $\mathrm{N}$ from 30 to 50) with their results presented on contour diagrams (Mean lineation vector V1, Eigenvalues $S_{1}$ and $S_{3}$; Figs. 8, 9, 11). The measurements of the orientation of glaciodynamic structures were presented on the dot diagrams. As a result of the petrographic analysis of the fine-grained gravel fraction of the tills the following rocks were delimited: northern rocks: crystalline rocks $(\mathrm{Kr})$, limestones $(\mathrm{Wp})$, dolomites $(\mathrm{Dp})$, shales ( $\mathrm{Lp})$, sandstones $(\mathrm{Pp})$, quartz $(\mathrm{Qp})$, and local rocks $(\mathrm{L})$. Moreover, the following petrographic coefficients were calculated: $\mathrm{K}=\mathrm{Kr}+\mathrm{Qp}, \quad \mathrm{O}=\mathrm{WP}+\mathrm{Dp}+\mathrm{Pp}+\mathrm{Lp}, \quad \mathrm{W}=\mathrm{Wp}+\mathrm{Dp}$, $\mathrm{A}=\mathrm{Wp}+\mathrm{Dp}+\longleftarrow \mathrm{p}, \mathrm{B}=\mathrm{Kr}+\mathrm{Qp}+\mathrm{Pp}$.

Frosting and rounding analyses of Cailleux (1942) were performed on $0.5-0.8 \mathrm{~mm}$ quartz grains, with the modification of Goździk (1980) and MycielskaDowgiałło and Woronko (1998), in order to define: (1) the environment in which thick sandy series building deposits were accumulated, and (2) the character of the potential source deposits. 
Seven types of grains were determined, each of them referring to a specific environment: aeolian (RM, EM/RM), high-energy aqueous environment (EL, $\mathrm{EM} / \mathrm{EL}$ ), broken (C), angular and fresh (NU), and in situ weathering (OTHER). The analysis was performed on 17 samples collected at the site in Nowe Dąbie, 16 samples from the site in Wypaleniska and 28 samples from the exposure in Zielonczyn (Fig. 1). The selected samples with the surface of the quartz grains of 0.5-0.8 mm diameter were further micromorphologically tested using the scanning electron microscope (SEM). Additionally, the quartz content in each sample was calculated, as the amount of this material increases in the deposits subject to numerous redeposition events (Mycielska-Dowgiałło, 2007).

The OSL dating method, applying the single aliquots regenerative (SAR) dose protocol (Murray and Wintle, 2000; Wintle and Murray, 2006) was used for the age determination of fluvial deposits. At the excavation sites samples were collected under special cover and packed directly to plastic tubes, in order to prevent any accidental exposure to daylight. In laboratory, the sand grains of the diameters from the range $0.100-0.200 \mathrm{~mm}$ were extracted with help of wet sieves. Then, samples were cleaned with perhydrol $\left(38 \% \mathrm{H}_{2} \mathrm{O}_{2}\right.$ for at least 1 hour or until the reaction was stoped) and hydrochloric acid $(10 \% \mathrm{HCl}$ for at least 1 hour or until reaction became quiet) to remove organics and calcite, subsequently rinsed with distilled water and ethanol and dried. After that, the quartz grains were extracted using floating method (heavy liquids prepared as solutions of sodium polytungstate: $2.70 \mathrm{~g} / \mathrm{cm}^{3}$ and subsequently $2.62 \mathrm{~g} / \mathrm{cm}^{3}$ ). Then quartz grains were etched in hydrofluoric acid (40\% HF for 40 minutes), which removed the outer layer of grains and etched out any remains of feldspar in the samples. The etching process was stopped with help of hydrochloric acid (10 minutes in $10 \% \mathrm{HCl}$ ), then samples were rinsed with distilled water, ethanol and dried. The purity of samples was checked by routine IR OSL tests. After applying laboratory dose no IR OSL signal was observed that confirms the absence of feldspar contaminations in the samples.

The Riso reader, model T1/OSL-DA-12 equipped with xenon lamp and excitation filter pack GG-420 (410-580 $\mathrm{nm})$ for stimulation and PM with U-340 filter (290-370 $\mathrm{nm})$ for detection was used for OSL measurements (Bøtter-Jensen and Duller, 1992). The beta source $\left({ }^{90} \mathrm{Sr} /{ }^{90} \mathrm{Y}\right)$ with dose rate of $41 \mathrm{mGy} / \mathrm{s}$ was applied for irradiations.

For every sample 24 aliquots (each one containing 5 $\mathrm{mg}$ of quartz grains) were used for OSL-SAR measurements $\left(100 \mathrm{~s}\right.$ of stimulation at $\left.125^{\circ} \mathrm{C}\right)$. The tests of preheat temperature were carried out at: $180^{\circ} \mathrm{C}, 200^{\circ} \mathrm{C}$, $220^{\circ} \mathrm{C}, 240^{\circ} \mathrm{C}, 260^{\circ} \mathrm{C}$ and $280^{\circ} \mathrm{C}$, using five aliquots for every specific temperature. On this base the annealing for $10 \mathrm{~s}$ at $240^{\circ} \mathrm{C}$ was chosen as the best preheat procedure (Fig. 2). From now on in the presented figures the regen- eration doses are termed in seconds of beta irradiation time in order to avoid taking into account $2 \%$ of uncertainty of laboratory beta dose rate calibration. The test doses, applied for monitoring sensitivity changes were fixed on the level of $10 \%$ of expected equivalent dose $\left(D_{E}\right)$ values. For calculations only the beginning part of OSL decay curve (0-1.2 s) was used. The OSL was stimulated by the Green Light for $100 \mathrm{~s}$, and it was checked out, that it is enough to totally bleach OSL signal to the PM background level (Fig. 3). However, in our

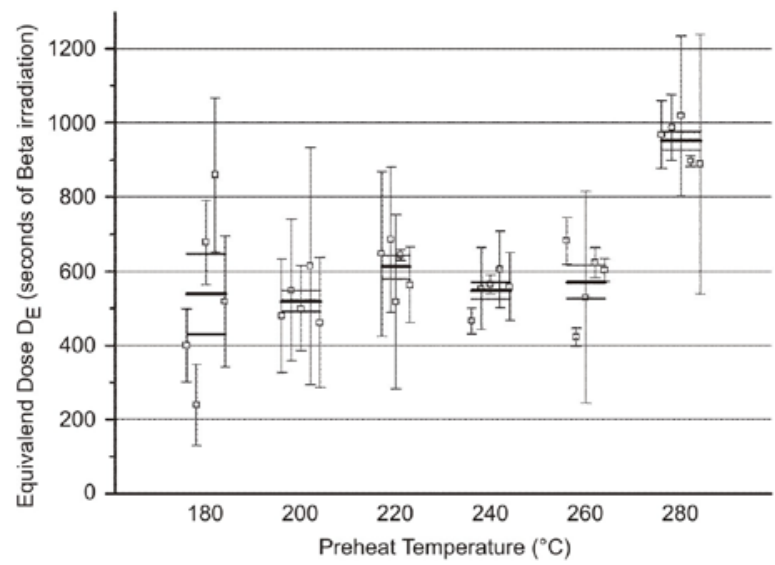

Fig. 2. Results of preheat tests obtained for the sample T0127. Symbols represent $D_{E}$ values obtained for individual aliquots preheated for 10 seconds at the given temperature. The bold line segments denote $D_{E}$ values averaged for every group of aliquots. Thin line segments indicate standard error limits. The least dispersion of $D_{E}$ was obtained for procedure with preheat at $240^{\circ} \mathrm{C}$. Results for the others samples were similar.

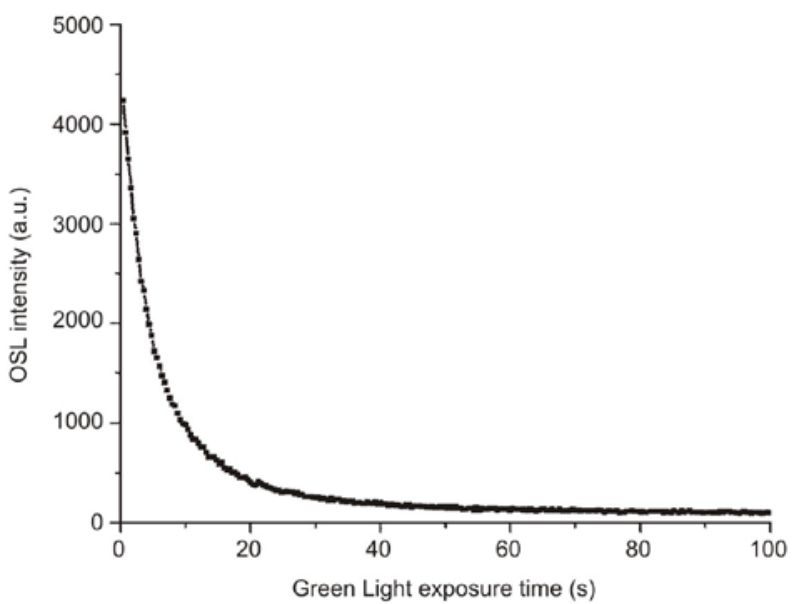

Fig. 3. Typical shine-down OSL curve presented by the sample T0124. After $100 \mathrm{~s}$ of exposure to the stimulating Green Light (GL: 410-580 $\mathrm{nm}$ with the total intensity at the disk position in the order of $160 \mathrm{~W} / \mathrm{m}^{2}$, after Bøtter-Jensen and Duller, 1992) the signal decays to the level of 90 counts, while the PM background is usually in the range from 20 up to 150 counts. 
routine procedure of data analysis the signal from the end part (from $98.8 \mathrm{~s}$ to $100 \mathrm{~s}$ ) of the preceding OSL decay curve is always subtracted. The effectiveness of this procedure was tested in the recuperation experiment (see Fig. 4) which results showed that after bleaching the residual OSL signal is lower than $1 \%$ of $D_{E}$ value. After bleaching the recovery tests were carried out.

The values of regeneration doses $D_{i}$ were set up to cover the range around expected $D_{E}$ value, predicted from the results of preheat tests. The preheat $\left(10 \mathrm{~s}\right.$ at $\left.240^{\circ} \mathrm{C}\right)$ and OSL readout $\left(100 \mathrm{~s}\right.$ at $\left.125^{\circ} \mathrm{C}\right)$ conditions were kept the same during the whole SAR procedure (for measurements of regenerated OSL as well as in the calibration steps applied for sensitivity correction). For every aliquot the growth curve was constructed (Fig. 5) and the linear function was fitted to the points nearest to the level of natural OSL signal. On this base the $D_{E}$ value was calculated. For single aliquot the uncertainty of $D_{E}$ value originates mainly from limited quality of linear fit and uncertainty of natural OSL signal (Duller, 2007).

The recuperation effect was studied by measuring the GLOSL reply of the samples after applying zero dose (Fig. 4). Then, the regenerative dose value, which was applied as the first one $\left(D_{1}\right)$, was repeated $\left(D_{5}=D_{1}\right)$ and the measured GLOSL signal was used to determine the recycling ratio (Fig. 6). Its value is defined as the proportion of regenerated GLOSL signal after dose D1 to that one after dose D5. The aliquots exhibiting the ratio values lower than 0.9 or higher than 1.1 (usually less than 4 aliquots in the series of 24) were excluded from averaging $D_{E}$ results. For some samples relatively wide distributions of single aliquot $D_{E}$ values were observed and we discuss this problem in details in separate paper (Weckwerth et al., 2011). At the end of our SAR procedure the IR OSL signal was monitored for detecting aliquots affected by potential impurities of feldspar contaminations. For this purpose the same regeneration dose, as used

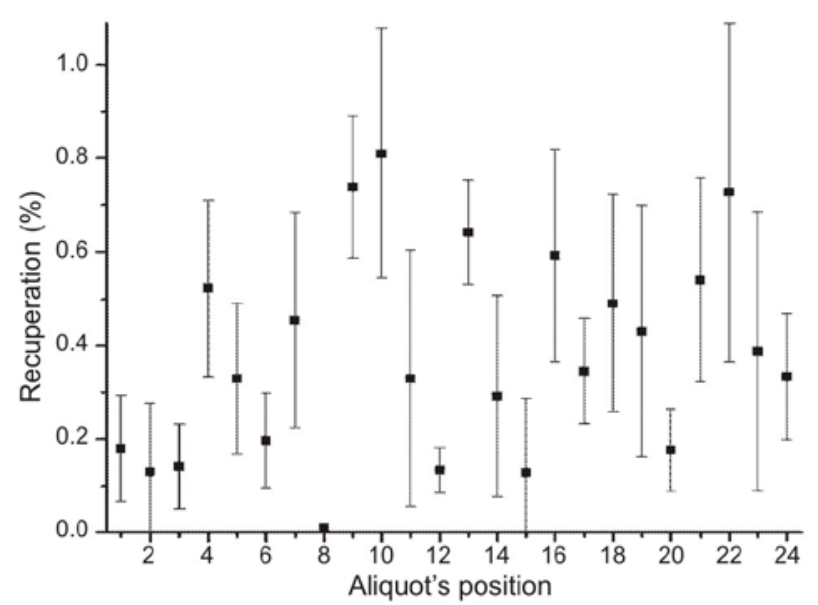

Fig. 4. The recuperation effect exhibited by aliquots of T0132 sample after applying regeneration dose $D_{4}=0 \mathrm{~s}$. The GLOSL residual values are termed as percentage of $\mathrm{D}_{\mathrm{E}}$ values. earlier for recycling ratio $\left(D_{1}\right.$ and $\left.D_{5}\right)$ was administered again and IR OSL signal and post IR GLOSL signal were measured (Fig. 7).

The annual dose rates $\left(D_{r}\right)$, comprised of beta and gamma radiations, were calculated on the base of gamma spectra measured in laboratory (sample amount of 600 ml) with help of Canberra System 100 spectrometer equipped with an HPGe detector. Usually 15 isotopes were detected and their activities were measured. On this base the activities of the rest of involved radio-isotopes were estimated and accounted for in calculations of $D_{r}$ values. The correction for water content and the compo-

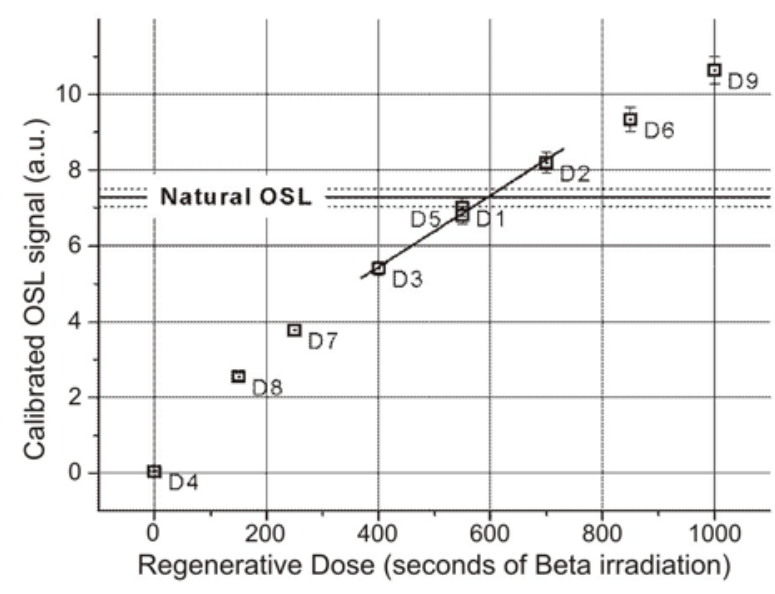

Fig. 5. The growth curve constructed for the sample T0132 can serve as typical example. The linear function was fitted only to the data points closest to the level of Natural OSL (represented by the bold line accompanied by thin lines indicating error limits). Due to this restriction to tight range of regenerative doses the assumed linear dependence of OSL signal on the applied dose is justified.

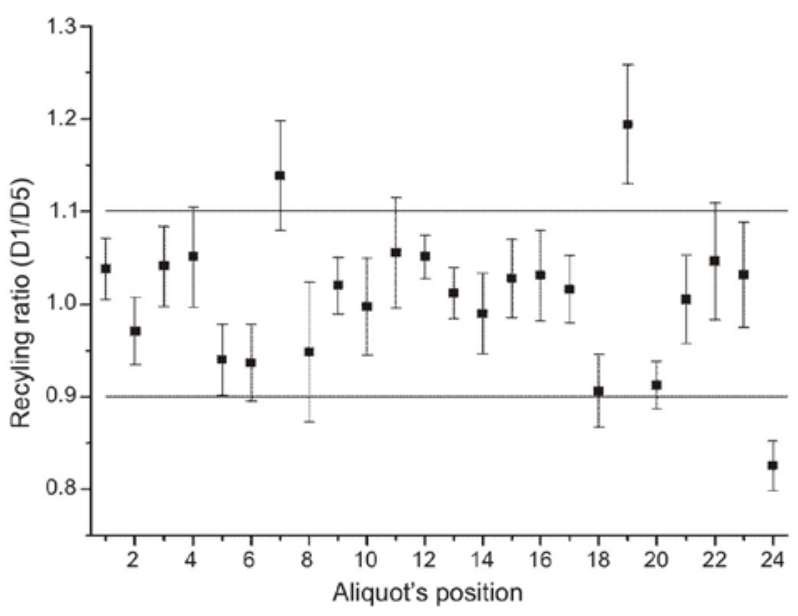

Fig. 6. The recycling ratio results obtained for aliquots of the sample T0132. The range of accepted values extends from 0.9 to 1.1 and its limits are marked by the horizontal lines. The data obtained from aliquots which don't fit to the specified range (here positions: 7, 19 and 24) are not taken into account in averaging $D_{E}$ values. 
nent of cosmic radiation were also taken into account (Oczkowski and Przegiętka, 1998; Oczkowski et al., 2000).

\section{RESULTS}

The lithofacial and textural research of the above mentioned sand deposits, together with the OSL dating, enabled the authors to identify in the Torun Basin and in the lower section of the Drwęca Valley a few series of

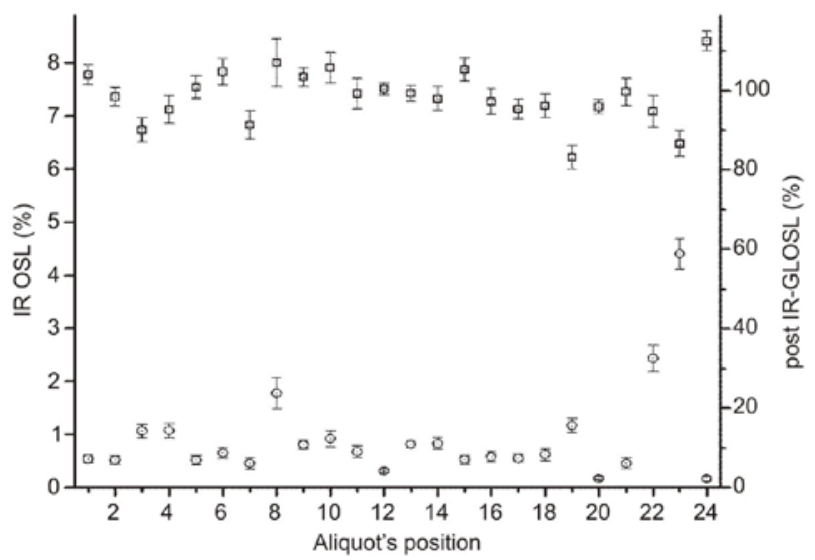

Fig. 7. The outcome from monitoring the sample T0132 for aliquots affected by potential impurities of feldspar grains. The results of $I R$ OSL (circles, corresponding scale on the left axis) and post IR GLOSL (squares, the scale given on the right axis) are termed as the percentage of GLOSL signal values measured directly after applying $D_{1}$ regeneration dose. All the aliquots were found to fit into the desired range of limits: below $5 \%$ for IR OSL and above $80 \%$ for post IR GLOSL. fluvial deposits which were accumulated before the Leszno Phase of the last glaciation. Dating the bottom part and the top of the sedimentary unit was aimed at determining the start and the end of the deposition of one fluvial series. Since the OSL ages of the samples overlap each other by their uncertainty margins, the dating resolution turns out to be too low in comparison with apparently short deposition time. It is possible to identify only approximate age, representative for whole sedimentary unit, fixed as the average value of the OSL dates obtained from appropriate sand layers.

\section{The oldest fluvial series}

Fluvial deposits was recognized in the Młyniec site, which is located in the lower section of the Drwęca Valley. The unit M1 have over $5.5 \mathrm{~m}$ thick (Fig. 8). It is represented by two groups of lithofacies. The first one $\mathrm{Si}$ - is mainly built from medium - to fine-grained sands with large-scale inclined stratification $\mathrm{Si}$ (laminas dipping at angle of $10-12^{\circ}$ to the south-east, Fig. 8). The deposits' median grain diameter in the central set is $0.25-0.31 \mathrm{~mm}$, while in the top part it is $0.17 \mathrm{~mm}$. These deposits are overlain by the lithofacies association $S p(S t)$. They are dominated by medium-grained planar cross-bedded sands and slightly coarser grains ( $d_{50}$ from 0.42 to $0.52 \mathrm{~mm}$ ) in relation to the underlying lithofacies $S i$. The above-lying medium-scale lithofacies $S p$ and $S t$ show lower median grain diameter $(0.32-0.34 \mathrm{~mm})$. They are overlain by the lithofacies $S r, S F w, F w, S p$ and $S l$, which are built of medium-sorted fine-grained sands and silty sands. The orientation of the current structures of the analysed group of lithofacies indicates the eastern and south-eastern direction of the water flow. The sediments of the unit M1 were deposited about $200 \pm 30$ ka ago (Fig. 8, Table 1).

Table 1. List of OSL dates of sandy deposits in the Torun Basin, for the age estimates the combined standard uncertainty is given.

\begin{tabular}{|c|c|c|c|c|c|}
\hline Site & Sedimentary unit (lithofacies) & Lab number & OSL age (ka) & $D_{r}$ (mGy/a) & $D_{E}(G y)$ \\
\hline \multirow[b]{2}{*}{ Młyniec } & $\mathrm{M} 1(\mathrm{Sr})$ & T0150 & $200 \pm 30$ & $1.26 \pm 0.11$ & $250 \pm 25$ \\
\hline & M2 (Sr) & T0157 & $57 \pm 8$ & $1.24 \pm 0.10$ & $71 \pm 8$ \\
\hline \multirow{2}{*}{ Chobielin } & C1 (SFw) & T0160 & $38.3 \pm 4.7$ & $1.37 \pm 0.11$ & $52.5 \pm 4.9$ \\
\hline & $\mathrm{C} 1(\mathrm{Sr})$ & T0161 & $29.5 \pm 3.9$ & $1.13 \pm 0.10$ & $33.4 \pm 3.2$ \\
\hline \multirow{4}{*}{ Nowe Dąbie } & N1 (Sh) & T0119 & $32.1 \pm 3.0$ & $1.12 \pm 0.05$ & $35.9 \pm 3.2$ \\
\hline & $\mathrm{N} 1(\mathrm{Sr})^{\prime}$ & T0120 & $27.5 \pm 4.0$ & $1.12 \pm 0.06$ & $30.5 \pm 4.7$ \\
\hline & $\mathrm{N} 1$ (SI) & T0121 & $34.8 \pm 5.3$ & $0.84 \pm 0.04$ & $29.0 \pm 4.5$ \\
\hline & $\mathrm{N} 1(\mathrm{Sr})$ & T0122 & $38.2 \pm 4.2$ & $0.85 \pm 0.04$ & $32.6 \pm 3.6$ \\
\hline \multirow{3}{*}{ Łochowo } & $\mathrm{L} 1(\mathrm{Sr})$ & T0128 & $28.5 \pm 3.8$ & $1.27 \pm 0.11$ & $36.1 \pm 3.8$ \\
\hline & L1 (Sr) & T0129 & $24.3 \pm 3.2$ & $1.39 \pm 0.11$ & $33.8 \pm 3.6$ \\
\hline & $\mathrm{L} 2(\mathrm{Si})$ & T0130 & $37.6 \pm 4.4$ & $1.13 \pm 0.10$ & $42.6 \pm 3.2$ \\
\hline \multirow{2}{*}{ Tur } & $\mathrm{T} 1(\mathrm{Si})$ & T0131 & $24.0 \pm 3.3$ & $0.83 \pm 0.09$ & $19.8 \pm 1.8$ \\
\hline & $\mathrm{T} 1$ (Si) & T0132 & $17.6 \pm 5.2$ & $1.26 \pm 0.11$ & $22.3 \pm 6.4$ \\
\hline \multirow{4}{*}{ Wypaleniska } & W2 (Sr) & T0123 & $22.3 \pm 1.7$ & $1.83 \pm 0.08$ & $40.9 \pm 2.5$ \\
\hline & W2 (Sr) & T0124 & $22.1 \pm 1.5$ & $1.54 \pm 0.07$ & $34.1 \pm 1.8$ \\
\hline & W1 (Sp) & T0126 & $29.2 \pm 2.6$ & $1.00 \pm 0.05$ & $29.4 \pm 2.2$ \\
\hline & W2 (Sr) & T0127 & $23.9 \pm 1.6$ & $1.02 \pm 0.05$ & $24.5 \pm 1.1$ \\
\hline \multirow{3}{*}{ Zielonczyn } & Z1 (Sp) & T0162 & $28.5 \pm 3.4$ & $1.17 \pm 0.10$ & $33.3 \pm 2.8$ \\
\hline & $\mathrm{Z3}$ (Sr) & T0158 & $26.9 \pm 3.2$ & $1.30 \pm 0.11$ & $34.9 \pm 3.0$ \\
\hline & $\mathrm{Z3}(\mathrm{Sr})$ & T0159 & $25.4 \pm 2.5$ & $1.38 \pm 0.11$ & $35.1 \pm 2.0$ \\
\hline
\end{tabular}




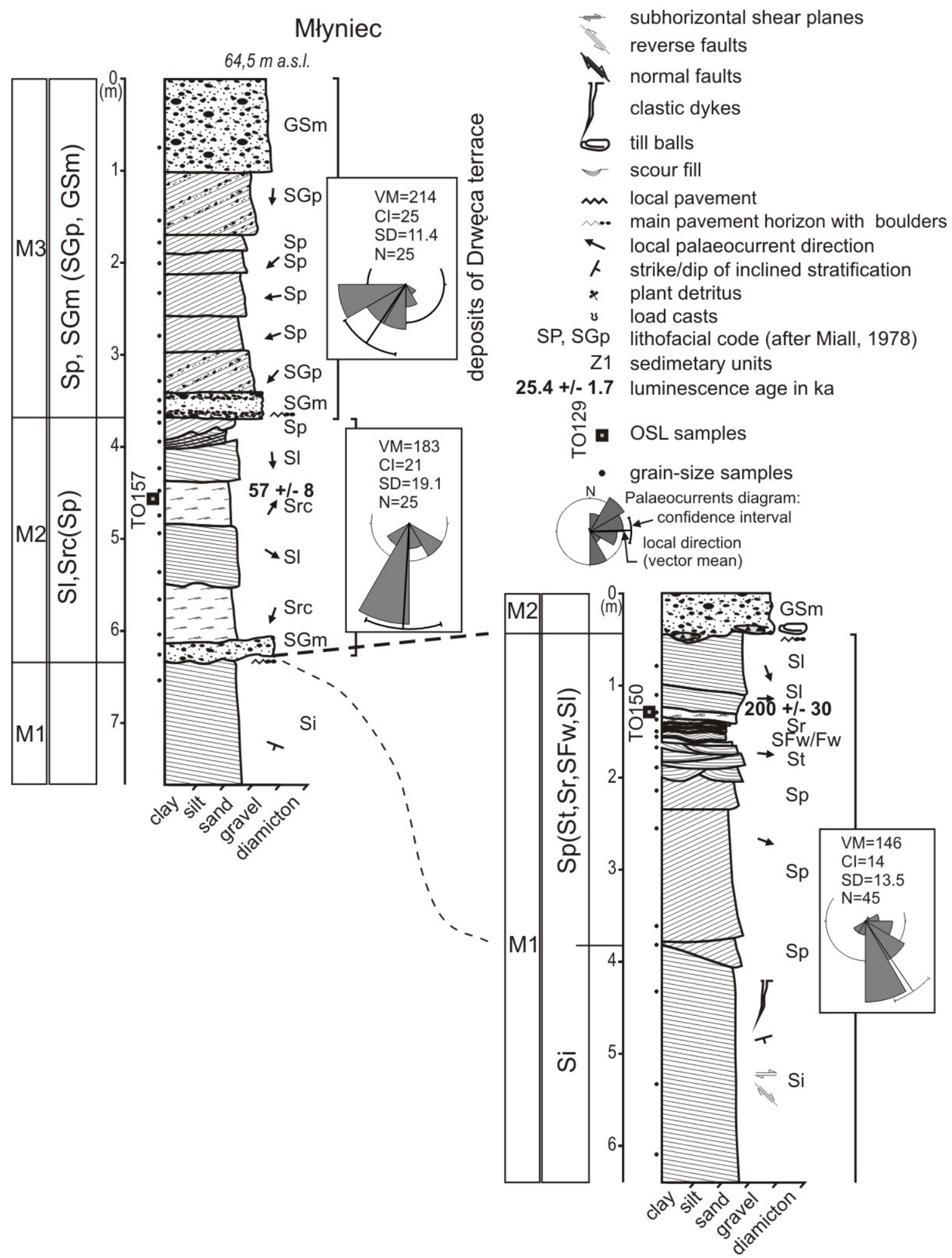

Fig. 8. Geological structure of the oldest and younger fluvial series in the mouth section of the Drwęca Valley (Młyniec site). 


\section{The younger fluvial series}

The younger fluvial series in the Torun Basin and the Drwęca Valley, is represented by sandy deposits and, locally, sandy-gravel ones up to $12 \mathrm{~m}$ thick in the analysed exposures. Their top reaches the altitude of 60-65 m or $83 \mathrm{~m}$ above sea level (Figs. 8, 9).

The deposits which belong to the younger fluvial series show considerable lithofacial diversity. At the Nowe Dąbie 1 site this series is located below the till layer (unit N2) developed as an brown and massive silty-sandy diamicton (Fig. 9). The bottom part of the till layer transforms into a sandy and silty diamicton which contains numerous little sandy folds and budins intersected by reverse faults. The underlying sandy deposits of the younger fluvial series (N1) include a few sets of lithofacies. In the exposure the bottom position is taken by the lithofacies association $S p(S h, S r, S t)$. They include well sorted fine-grained sands and fine- and medium-grained sands ( $d_{50}$ from 0.15 to $0.25 \mathrm{~mm}$ ) having medium sorting. Locally, the sets of tabular bedding include backflow ripple structures. Generally, the water flow had the western direction. In the top these deposits change into fine- grained sands of ripplemark lamination $\left(d_{50}\right.$ from 0.14 to $0.17 \mathrm{~mm})$. The overlying lithofacies association $S r, S r c, S F h$ is up to $2.1 \mathrm{~m}$ thick. It is built of fine-grained sands ( $d_{50}$ from 0.13 to $0.17 \mathrm{~mm}$ ) which are dominated by the ripple lamination, including climbing ones. Further up there are the next sets $S p(S l, S r, S t)$ found in the Nowe Dąbie profile 1 and $S p(S r, S t)$ in the Nowe Dąbie profile 2 , which are up to $4.75 \mathrm{~m}$ thick. They are built of fineand medium-grained sands. Lithofacies of tabular and low-angle stratification reach up to $2 \mathrm{~m}$ and $1.2 \mathrm{~m}$, respectively. In their top, the deposits are cut through by a medium-sized lithofacies of medium-grained sands $S t$ and horizontally bedded sands. These deposits are extended up with a 0.4-metre layer of fine-grained sands of ripple lamination and medium-sized lithofacies $S p$. The azimuth of the palaeoflow, determined on the basis of the orientation of the structures of the cross-bed structures, amounts from $233^{\circ}$ to $242^{\circ}$. The upper part of the discussed set in the Nowe Dąbie 1 profile (lithofacies $S p$ ) has its continuation in the Nowe Dąbie 2 profile (Fig. 9). Their sets dip towards south-east, while the laminas indicate the northwestern direction of the palaeocurrent $\left(285^{\circ}-332^{\circ}\right)$. Except for this, in the Nowe Dąbie 2 profile there is a litho-

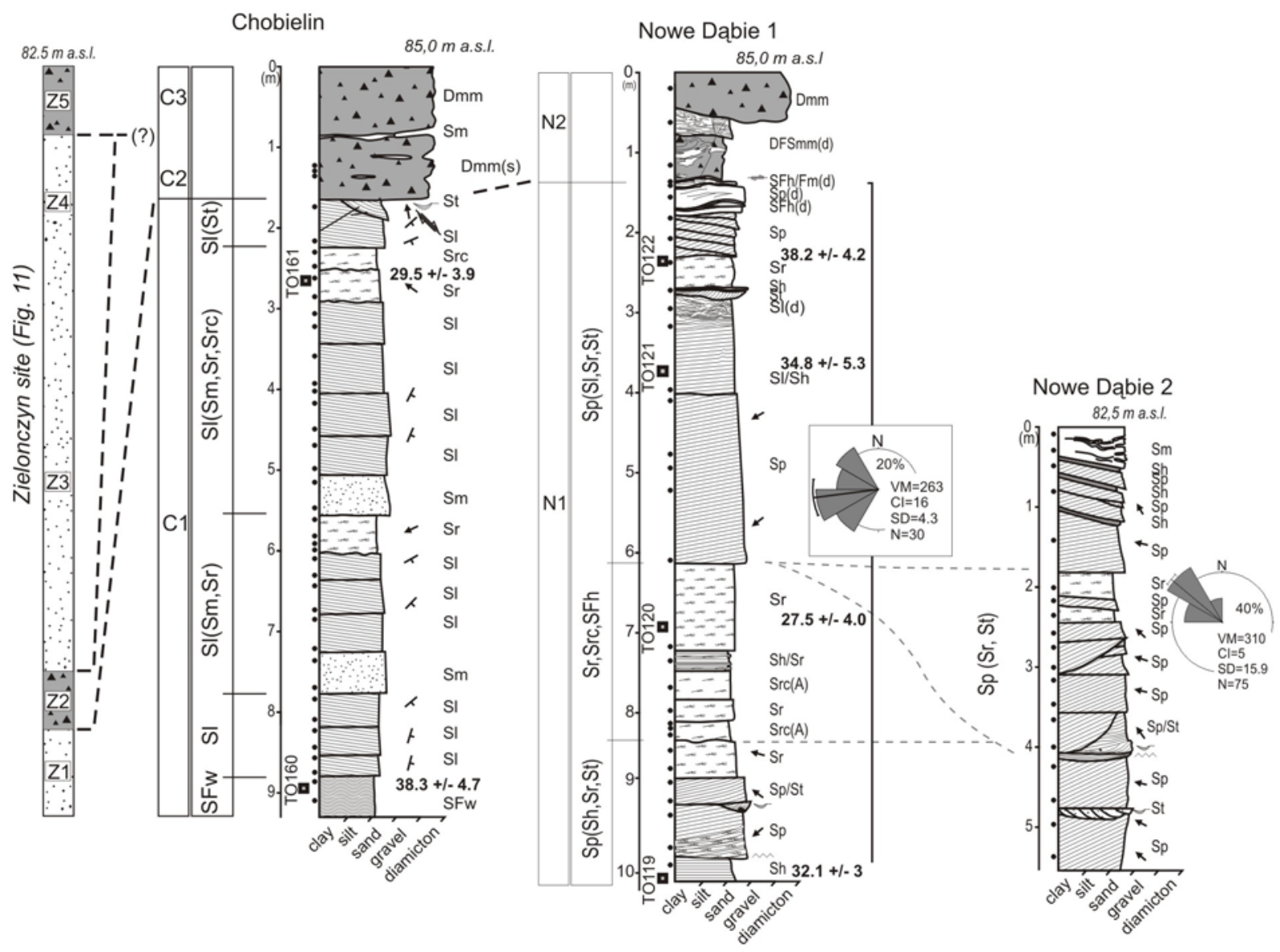

Fig. 9. Sedimetary logs of the younger fluvial series (sites: Chobielin and Nowe Dąbie). Explanations of structural features like in Fig. 8. 
facies association $S p(S r, S t)$ below (at the depth 1.8-4.1 m, Fig. 9). Predominantly, these are large- and mediumscale tabular cross-stratification, locally cut by fillings of shallow channels $(S t)$ and extended up with a layer of fine-grained sands of ripple lamination. These deposits belong to a coarser fraction in relation to the lithofacially corresponding layers in the Nowe Dąbie 1 profile. Despite this, the orientation of the sedimentological structures is similar and indicates the value of the palaeocurrent's azimuth from $284^{\circ}$ to $315^{\circ}$. The age of the deposits at Nowe Dąbie site is c.a. $33 \mathrm{ka}$ (Table 1).

The results of the rounding and frosting of the quartz grains from the Nowe Dąbie site indicate that the EL and $\mathrm{EM} / \mathrm{EL}$ grains are dominant and make up from 55.3 up to $97.5 \%$. A large contribution (from 8.3 to $33.3 \%$ ) is made by the grains of insignificant rounding $(>0.7$ according to the Krumbein (1941) scale of rounding). Furthermore, these grain samples also contained fractured grains (C) which are the outcome of damaging the grains of either EL or EM/EL type. Their contribution is insignificant and does not amount to more than $6 \%$.

The younger fluvial series also includes the sandy deposits exposed in the site of Chobielin (Fig. 1, Fig. 9). They lie directly beneath till layer which is formed of silty diamicton of light-brown colour and the thickness of about $1.7 \mathrm{~m}$. In this till at the depth of $0.8-0.9 \mathrm{~m}$ there is a non-continuous layer of fine-grained sands. The contact between the diamicton and the underlying fluvial deposits is flat and clear (Fig. 10). The petrographic analysis of the lower part of diamicton layer (unit C2, Fig. 9) shows a larger share of limestones $(40.2-46.6 \%)$ than crystalline rocks $(26.9-30.8 \%)$. The content of sandstones is $4.7-$ $9.8 \%$ and percentage of local rocks reaches from 12.4 to $13.7 \%$. The mean values of the petrographic coefficients are: $\mathrm{O} / \mathrm{K}=1.9, \mathrm{~K} / \mathrm{W}=0.6, \mathrm{~A} / \mathrm{B}=1.3$. The underlying fluvial series in this site is over $7.5 \mathrm{~m}$ thick. In the bottom part of the exposure there is lithofacies $S F w$ built of moderately

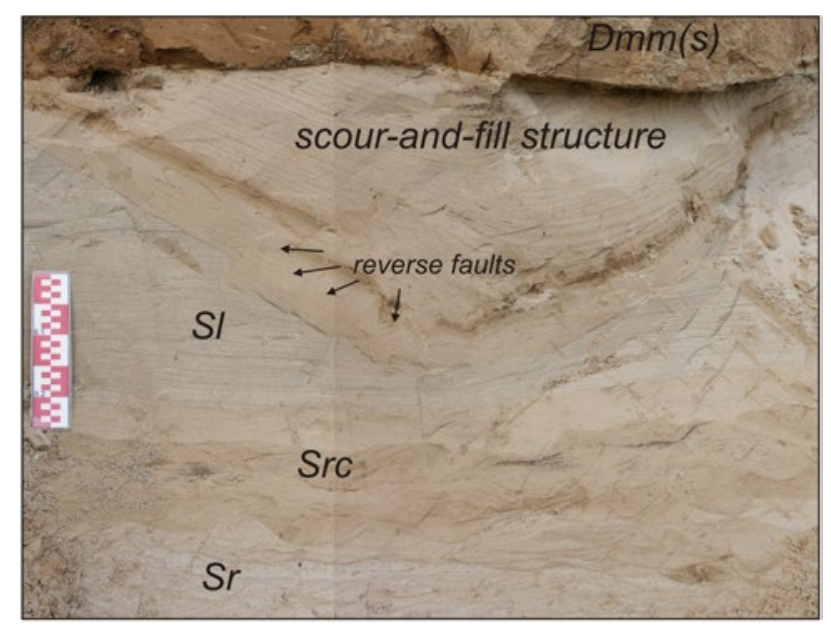

Fig. 10. Scour-and-fill structure in the upper part of younger fluvial series at Chobielin site. and moderately well sorted fine-grained sands $\left(d_{50}\right.$ $0.15 \mathrm{~mm}$ ). Above the profile has fine-grained sands of four cycles of fluvial deposition: $\mathrm{Sl}, \quad \mathrm{Sl}(\mathrm{Sm}, \mathrm{Sr})$, $S l(S m, S r, S r c)$, and $S l(S t)$ (Fig. 9). They are predominantly medium- and, locally, large-scale cosets $S l$, built of well and moderately well sorted fine-grained sands the laminas of which dip at the angle of $6-8^{\circ}$ in the south-east direction. In most of these lithofacies, the beginning of the finning upward cycle is visible. The bottom part of the full sequence of the lithofacies is built of fine-grained sands of a bit coarser grains and massive structure $\mathrm{Sm}$, and it is topped by a fine-grained sands in ripple laminated cosets $(\mathrm{Sr}$ or $\mathrm{Src}$ ). Moreover, in the top zone of the fluvial series there is a scour-and-fill structure of the maximum depth of the cut of $0.45 \mathrm{~m}$ and the width of $2.5 \mathrm{~m}$, deformed by a number of reverse faults (Fig. 10). The orientation of the sandy laminas which fill up this structure indicate the north direction of the water flow. In accordance with the results of the dating of the deposits of the fluvial series at the site of Chobielin the deposition took place c.a. 34 ka ago (Fig. 9, Table 1).

At the mouth section of the lower Drwęca Valley the younger fluvial series includes the deposits of the unit M2, which are clearly separated from the unit M1 (the oldest fluvial series from the Saalian Glaciation) by a continuous layer of the channel lag deposits with brown till balls (Fig. 8). At the site of Młyniec the younger fluvial series is represented by a set of medium- and largescale lithofacies association $S l, S r c(S p)$. They are built of moderately well sorted fine-grained sands, although the lithofacies $S p$ and $S l$ have a little coarser grains $\left(d_{50} 0.53\right.$ $0.56 \mathrm{~mm}$ ). In most cases the laminas of cross-bedding in the unit M2 dip into the south. The age of these deposits is $57 \pm 8 \mathrm{ka}$ (Fig. 8, Table 1).

The younger fluvial series is possibly exposed at the lower section of Wypaleniska site (Fig. 11). It is mainly represented by medium-grained sands and gravels which build lithofacies association $S G p, S p(S G m)$ (unit W1, Fig. 11).

\section{The youngest fluvial series}

The youngest fluvial series was recognised in the sites of Łochowo, Tur, Wypaleniska and Zielonczyn (Fig. 1, Fig. 11). In these profiles it is located below the till layer which builds the surfaces of the pradolina terraces, or between two layers of till (the Zielonczyn site).

In the lower section of the exposure at the site of Łochowo, the lithofacies association $\operatorname{SFh}, \operatorname{Src}(\mathrm{Sw})$ is recorded. It is built of fine-grained and silty sands of ripple lamination (including climbing ripples) and horizontal lamination, as well as massive silts. Locally palaeoflow was directed to the north-west and south-west (Fig. 11). These deposits are overlain by the sandy-gravel unit L2. It fills up a buried channel about $5 \mathrm{~m}$ deep. Its bottom is marked by an erosive surface of a concave character, which cuts the deposits of the unit L1. Above the erosive surface there is a layer of channel lag deposits of 0.75 - 


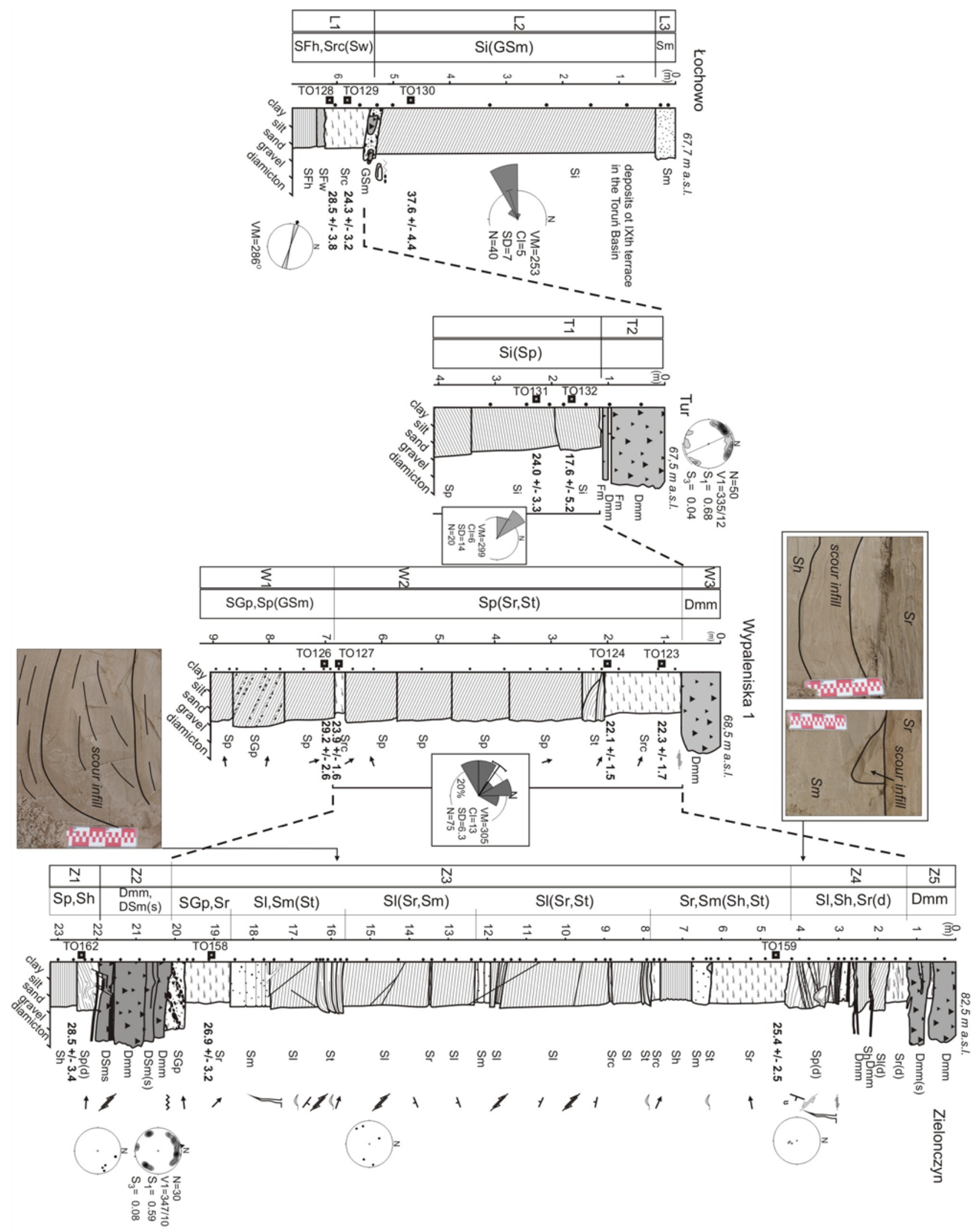

Fig. 11. Sedimetary logs of the youngest fluvial series (sites: Łochowo, Tur, Wypaleniska and Zielonczyn) and an examples of the scour-and-fill structures in the middle and upper part of the Zielonczyn formation. Explanations of structural features like in Fig. 2. 
$0.15 \mathrm{~m}$ thickness which includes boulders and till balls surrounded by coarse-grained sands with gravel $(G S m)$. Sporadically, gravel fractions form laminas here, the course of which is concordant with the shape of the till balls. The samples of fine-grain gravel collected from the largest till balls were tested petrographically. As the results of the analysis indicated, limestones dominate (48.4$58.6 \%)$ over crystalline rocks $(29-35 \%)$. The share of the sandstones is $7.7-8.2 \%$, while the percentage of local rocks is from $1.9 \%$ to $5.1 \%$. The value of the petrographic coefficient $\mathrm{O} / \mathrm{K}$ amounts from 1.5 to 2.3 , the coefficient $\mathrm{K} / \mathrm{W}$ from 0.5 to 0.8 and the coefficient $\mathrm{A} / \mathrm{B}$ from 1.1 to 1.6. The above results of the petrographic analyses are concordant with the petrographic composition of the gravel in the till at the Tur site.

At the site of Łochowo the main part of the unit L2, above the channel lag deposits, is built of medium- and fine-grained sands of the planar cross-bedded of exceptionally large scale $(\mathrm{Si})$. This lithofacies reaches maximum $4.7 \mathrm{~m}$ along the axis of the buried form. The laminas of coarse-grained sands with fine gravels which are found there reach up to $2 \mathrm{~cm}$, while those of fine-grained sands up to $7 \mathrm{~cm}$. Further up in the profile successive decrease in the thickness of these laminas for more coarse-grained laminas was recorded. Among the thickest layers of fine-grained sands backflow ripple lamination are found sporadically. Towards the top of the lithofacies $S i$ mean grain diameter increases while the sorting of the material changes from medium to weak. The orientation of the laminas of the lithofacies $S i$ indicates the west and south-west direction of the water flow. This direction can be related with the orientation of the buried channel under scrutiny.

The deposits of the youngest fluvial series are also exposed at the site of Tur (Figs. 1, 11). They lie beneath till 1.1-1.25 $\mathrm{m}$ thick and are represented by fine- and medium-grained of planar cross-bedded sands, which in the top turn into silts with partly preserved horizontal lamination. The orientation of the laminas in the lithofacies of tabular cross-stratification shows the deposit was accumulated by the waters flowing in the north-west direction (VM=299 ${ }^{\circ}$, Fig. 11). At the site of Tur their age is c.a. $21 \mathrm{ka}$ (Table 1$)$.

At the profile of Wypaleniska the youngest fluvial series is mainly represented also by fine- and mediumgrained sands which build lithofacies association $S p(S r, S t)$ (unit W2, Fig. 11). Their bottom is marked by well sorted fine-grained sands ( $d_{50}$ from 0.14 to $0.18 \mathrm{~mm}$ ) of the ripplemark lamination (including climbing ripples) or localy $S G p$ which turns into massive gravels with boulders $S G m$ and rounded till balls. The above-lying lithofacies $S p$ are up to 0.8-1.3 m thick. They are mainly built of medium-grained sands (median grain diameter $d_{50}$ from 0.27 to $0.31 \mathrm{~mm}$ ) which are moderately and moderately well sorted. Moreover, in the top of the unit W2 appear medium-grained, trough-cross bedded sands $S t$. In accordance with the results of the OSL dating the ana- lysed series at the site of Wypaleniska was deposited up to 21 ka ago (Fig. 11, Table 1).

A diverse development of the lithofacies of the youngest fluvial series can be observed at the site of Zielonczyn (unit Z3, Fig. 11). The results of the OSL dating for these deposits indicate that their accumulation took place c.a. $26 \mathrm{ka}$ ago (Fig. 11, Table 1). This series is located between two layers of till. The bottom of the 2-m thick till layer (unit Z2) is represented by a sandy massive diamicton of light brown colour with light beige lenses of fine-grained sands. At its top it turns into a brown massive diamicton with little detached folds and lenses of fine-grained sands which are cut by normal faults of 1-8 cm slip. The till fabric date indicate north to south direction ice movement $\left(\mathrm{S}_{1}\right.$ is 0.59 , while $\mathrm{S}_{3}$ is 0.08$)$. The results of petrographic analysis indicated, that limestones $(46.4 \%)$ dominated over crystalline rocks $(33 \%)$. The sandstones reaches $6.2 \%$, while the percentage of local rocks is $9.4 \%$. The petrographic coefficient are: $\mathrm{O} / \mathrm{K}=1.7$, $\mathrm{K} / \mathrm{W}=0.7$ and $\mathrm{A} / \mathrm{B}=1.3$. The petrographic composition of the lower till in Zielonczyn site (unit Z2) is similar to the till in the Chobielin site (unit C2, Fig. 9).

The top of the diamicton at the Zielonczyn profile (unit Z2) is eroded and covered with gravels and sand which belong to the youngest fluvial series (unit Z3, Fig. 11). In one of the studied profiles of the Wypaleniska site the described till includes till balls within the gravelsandy lithofacies of channel lag deposits of the youngest fluvial series. The thickness of the youngest fluvial series at the site of Zielonczyn is a bit over $16 \mathrm{~m}$ and is located at the altitude of 62-78.5 m above sea level (Fig. 11). The complex of these deposits includes five sets of lithofacies. The lower position is taken by the lithofacies association $S G p, S r$, at the bottom of which poorly sorted sandy gravels are recorded, which further up turn into gravely planar-cross bedded sands and fine-grained sands of the ripple lamination $S r$. The orientation of the laminas of tabular cross-stratification shows the west direction of the river flow. The layers further up belong to three similar cycles of sedimentation: $S l, S m(S t), \quad S l(S r, S m)$ and $S l(S r, S t)$. They are dominated by cosets of large-scale lithofacies $S l$ 0.8-2.6 m thick. They are built of well sorted fine-grained sand ( $d_{50}$ from 0.15 to $\left.0.16 \mathrm{~mm}\right)$. The laminas of the lithofacies $S l$ dip at 6-10 ${ }^{\circ}$ into the northeast, south-east and south-west. The sands of the lithofacies Sm, which are found at the bottom of the depositional cycles, include a bit coarser grains $\left(d_{50}\right.$ from 0.15 to $0.17 \mathrm{~mm}$ ) and poorer sorting. The upper range of the next cycles of sedimentation is marked by the lithofacies $S t$, which are connected with scour-and-fill structures and reach up to $0.35 \mathrm{~m}$ (Figs. 11, 12). They are built of finegrained sands ( $d_{50}$ from 0.16 to $0.17 \mathrm{~mm}$ ) of normal sequence of fractional graining.

The top part of the youngest fluvial series is built of a lithofacies association $S r, S m(S h, S t)$. In the bottom section these are moderately and well sorted fine-grained sands $(\mathrm{Sm})$. These sands upward turn into the ripple-cross lami- 


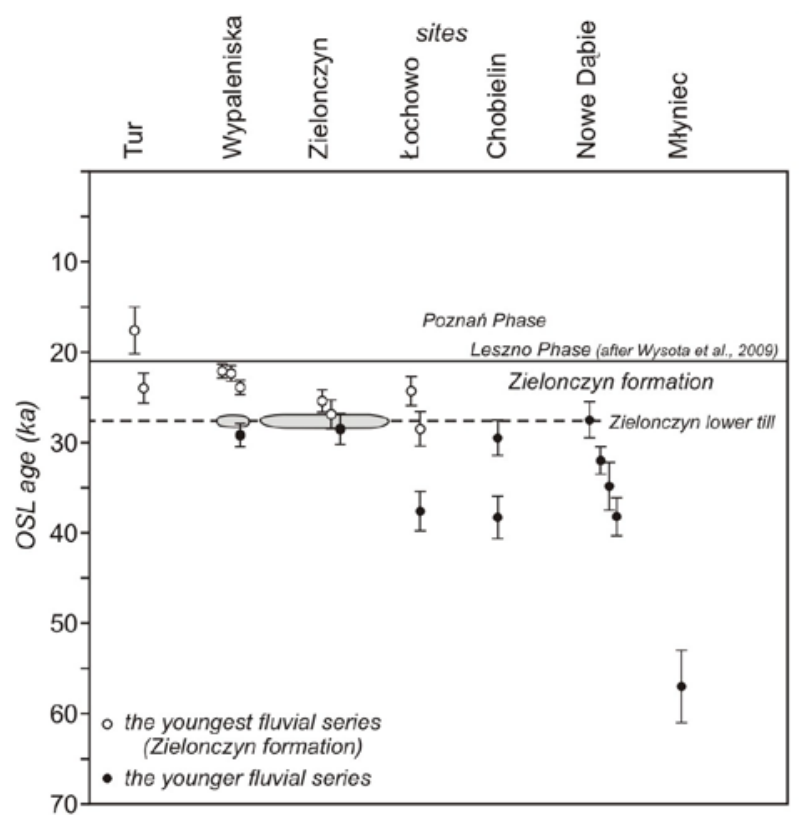

Fig. 12. Time diagram with luminescence dating (age and range) of Weichselian fluvial series in the Torun Basin and in the mouth section of the Drwęca Valley.

nation (Fig. 11). They show the gentle coarsening upward cycle, in which the median grain diameter $d_{50}$ increases from $0.13 \mathrm{~mm}$ to nearly $0.15 \mathrm{~mm}$.

Above the described the youngest fluvial series at the site of Zielonczyn there is a series of fine-grained sand deposits (Z4) of deformed primary sedimentological structure as well as interbeddings of brown clayey-silty diamicton. There are numerous reverse faults here, which are cut through by the structure of a clastic dike of about $0.2 \mathrm{~m}$ in diameter. Primarily, before the deformational processes took place, the deposits of the unit Z4 were building the top of the series Z3. These deposits are overlain by the till which builds morainic plateau (unit Z5, Fig. 11) or the surfaces of the pradolina terraces (units T2, W3, Fig. 11). In the first case it is represented by light brown, sandy diamicton of massive structure, at the bottom of which there are sandy folds and interbeddings. Within the Torun Basin (Tur site) this till is represented by brown diamicton of massive structure, where the intensity of the orientation of the longer axis of clasts is large $\left(\mathrm{S}_{1}=0.68 ; \mathrm{S}_{3}=0.04\right)$, while the maximum concentration shows the direction NW-SE. The petrographic analysis of the fine-grained gravel fraction of the diamicton shows a larger share of limestone $(47.2 \%)$ than crystalline rocks $(32.0 \%)$, as well as a significant share of sandstones $(10.1 \%)$ and local rocks $(5.6 \%)$. The values of the petrographic coefficients are: $\mathrm{O} / \mathrm{K}=1.5, \mathrm{~K} / \mathrm{W}=0.8, \mathrm{~A} / \mathrm{B}=1.0$, while the share of carbonates is $8.5 \%$.

The analyses of rounding and frosting of quartz grains at the Wypaleniska site indicate that the share of EL and $\mathrm{EM} / \mathrm{EL}$ grains is from 73.5 to $98.1 \%$, while in Zielonczyn from $64.2 \%$ to $93.6 \%$. Moreover, a large percentage of grains is very well rounded; at the Wypaleniska site it is 12.3 to $28 \%$ and at the Zielonczyn one $6.4-22.6 \%$. The percentage of fractured grains (C) at the Wypaleniska site is insignificant (up to 6\%). At the Zielonczyn profile, $\mathrm{C}$ varies and is in most cases high or very high $(>19 \%)$. Moreover, the results of the Cailleux analyses (1942) with the modification of Goździk (1980) and MycielskaDowgiałło and Woronko (1998) show that the tills at the Zielonczyn profile have a similar spectrum of grain types and both the underlying and overlying sandy deposits (units Z1 and Z3).

\section{DISCUSSION}

The geological structure of the slopes and erosive terraces of the Torun Basin as well as the lower section of the Drwęca Valley includes three fluvial series. They are predominantly built of sandy deposits and underlying a layer of till correlated with the advance of the Scandinavian ice sheet of the Leszno Phase during Late Weichselian (Wysota 2002; Wysota et al. 2009). According to Molewski (2007) and Wysota et al. (2009) within the Vistula Lobe this ice sheet had its maximum extent about $20.3 \mathrm{ka}$ ago and reached a bit further south from the Torun Basin.

The oldest fluvial series, which comes from the Saalian Glaciation, was identified at the mouth section of the Drwęca Valley (Fig. 8, Table 1). It includes lithofacies $S i$ of exceptionally large scale, the laminas of which show a successive change in the direction of the dipping as well as a significantly smaller angle of dipping in relation to the tabular sets also found in this place. It is almost perpendicular to the direction of the palaeocurrent delimited on the basis of the cosets $S p$ (Fig. 8). The interrelations and significant differences in the thickness of the lithofacies $S p$ and $S i$ indicate that was the development of sidebars rather than a laterally accreted mid-channel bar. They were developing along the banks of river channel of up to $5 \mathrm{~m}$ of water flowing through it. The coexisting cosets $S p$ were deposited due to the development of transverse bars which migrated there and covered sidebars. A similar development of the channel forms was described by Olsen (1988) in the sandy braidedmeandering river system in Germany and Schwartz (1978) in sand bed of the braided-to-meandering transition zone of the Red River. The lithofacial features of the oldest fluvial series might represent the mixed-load, laterally active channels of an anabranching river (Nanson and Knightom, 1996).

As far as the analysed sites are concerned, they contain neither a series which would be related to a meandering river from the Eem Interglacial as described by Makowska (1979) in the Torun Basin, nor any fluvial deposits from Lower Powiśle which were deposited by a braided river during the Early Weichselian (Wysota, 2002). This is caused by the fact that in the north part of the 
basin their top is at the altitude of about $35-40 \mathrm{~m}$ above sea level, i.e. much deeper than the sites analysed in this article. Due to this the older part of the Rzęczkowo formation (cycle $\mathrm{R}_{\mathrm{I}}$ ) was not found in the analysed sites (Wysota, 2002).

The younger fluvial series shows diverse lithofacial features. As the results of the OSL dating indicate, this series were accumulated in the upper part of Middle Weichselian, i.e. by about 29 ka ago (Fig. 12). They refer to the second stage of the deposition of the Rzęczkowo series $\left(\mathrm{R}_{\mathrm{II}}\right)$ which was found in the northern edge of the Torun Basin (Wysota, 2002; Wysota et al., 1996). The sandy deposits of the younger fluvial series are represented by a cyclical sequence of the lithofacies associations $S p(S l, S h, S t, S r) \rightarrow S r, S r c, S F h$. They were deposited by a sand-bed braided river, at the bottom of which developed aggradational forms at the initial phase of the waning flood (Cant and Walker, 1976; Zieliński, 1992; 1993). The dominant cosets $S p$ indicate the development of transverse bars, as well as a significant depth of the flowing water. The best developed lithofacies association of the younger fluvial series include $S p(S l, S r, S t)$ at the site of Nowe Dąbie (Fig. 9). It developed in the conditions of a limit between the upper and the lower stage of lower flow regime and as a result of the growth of large and complex transverse bars (Weckwerth, 2009a). At the same time, however, they might be the recording of the surfaces of reactivation being formed during the following floods (Collinson et al., 2006). These forms were moving west and south-west. Due to their large size their surfaces were variously modelled and depended on the depth of the river. The sections located deeper were covered with secondary lower and shorter sand bars or twodimensional dunes (the profile of Nowe Dąbie 2). The upper sections of the large bars were covered with shallow-water lithofacies $S h$ and $S l$ in the transition conditions to the upper regime of the water flow (the profile in Nowe Dąbie 1). Moreover, their emerging sections were being cut by the shallow channels of flowing water $(S t)$. In the other secondary channels smaller sand bars and two-dimensional dunes were migrating (Miall, 1985; Zieliński, 1992; 1993; 1998). The fading water flow triggered off the development of the ripplemark bottom. The waters flowed in the north-west direction. The finegrained sands and silts lithofacies $S r, S r c, S F h, S F w$ and $S F h$, found in the analysed sites, indicate the existence of a floodplain.

The lithofacial feature of the younger fluvial series in the Torun Basin (the site at Nowe Dąbie) show similarities to the lithotype of the lower section of the River Platte (Smith, 1970). Some similarities may also be found in relation to the deposits of the South Saskatchewan River (Cant and Walker, 1978). This river also shows and insignificant gradient, shallow and even bottom as well as the presence of the floodplain (sand flat lithotype). The riverbed deposits are well sorted here and $d_{50}=0.3 \mathrm{~mm}$.
The deposition of the younger fluvial series, which is exposed at the site of Chobielin, shows a different character. The common here medium- and large-scale lithofacies $S l$ with the secondary $S m$ and $S r$ might represent the subenvironment of shallow and wide braided river with dunes being washed away or a near-channel section of the floodplain covered with deposits during overbank floods (Zieliński, 1992). The dipping of the laminas within the cosets $S l$ is insignificant. This may indicate that the sand sheets were deposited by overbank sheet flows (Tunbridge, 1981; 1984), although the fine-grained sandy fraction indicates low energy of flowing water. On the other hand, however, the fact that there are large-scale lithofacies $S l$, which are covered either with sands of ripple lamination or by scour-and-fill structure, might suggest the development of point-bars sensu lato (Olsen, 1988). In this situation the younger fluvial series which is exposed in Chobielin would have been deposited in the sinuous individual channels of a braided system of 2.5-3 $\mathrm{m}$ depth. The river system, thus, had the character of a sand-dominated or mixed-load laterally active anabranching river (Nanson and Knighton, 1996).

The results of the OSL dating of the youngest fluvial series indicate that the deposition took place about 27-21 ka ago, which can be related to the upper part of Middle Weichselian and lower Late Weichselian when the landscape was dominated by herbaceous vegetation (Latałowa, 2003). The above-lying till (the site at Tur) shows similar petrographic composition to the till building the morainic plateau located to the west (the site of Samoklęski Małe, Weckwerth, 2004) as well as the till from Starogród Zamek and the upper unit of Łążyn till (Wysota, 2002). In the central and southern part of the Torun Basin the youngest fluvial series is dominated by medium- and large-scale lithofacies $S p$, the sets of which end up with a ripplemark cosets (Wypaleniska and Łochowo sites). Such a diverse lithofacial character corresponds with the deposits accumulated at the bottom of a sand bed braided river of dominant transverse bars sedimentation (Zieliński, 1992; 1993). The development of the lithofacies $S p$ indicates the changeable dynamics of the water flow and its decreasing depth. The west and north-west directions were dominant. As the OSL dating results indicate, the deposits of the unit L2 (the Łochowo site, Fig. 11) might be included into the fluvial series from the end of Late Vistulian. However, due to the similarity of petrographic composition of the till balls at the Lochowo site and the till layer at the Tur site as well as the fact that buried channel include the shallow palaeochannel on the surface of the pradolina terrace, the lithofacies $\mathrm{Si}$ (unit L2, the Lochowo site) might belong to the deposits of the IXth terrace of the Torun Basin (the pradolina terrace deposits, Weckwerth, 2010).

The youngest fluvial series also includes the inter-till sandy series from Zielonczyn (unit Z3, Fig. 11). It contains five cycles of deposition which are dominated by large-scale lithofacies $S l$ covered with sands of either 
ripple lamination or the scour-and-fill structure. Such lithofacies are characteristic for side-bar deposits (Olsen, 1988; Zieliński, 1998, Salamon and Zieliński, 2010). In its upper part they were being cut by chute channels or covered with fine-grained sands of ripple lamination or horizontal bedding (the lithofacies association $\mathrm{Sr}, \mathrm{Sm}(\mathrm{Sh})$, Fig. 11). The fact that there is a tabular lithofacies $S p$, which was later deformed glacitectonically, indicates there might have existed the chute bars (unit Z4, Fig. 11).

The lower till layer found in the exposure of the Zielonczyn site is located between the younger and the youngest fluvial series. The results of the OSL dating of theses fluvial deposits show that the tills' deposition took place c.a. 28 ka ago (Figs. 11, 12). The till fabric data show the north ice flow direction in the area of the Torun Basin. The chronostratigraphic position of the lower till from Zielonczyn corresponds with the Klintholm Till Unit (Houmark-Nielsen, 2007; 2010; Houmark-Nielsen and Kjær, 2003). In accordance with the suggestions of Houmark-Nielsen (2010) and Marks (2010) the Klintholm ice advance might have reached the northern part of Poland.

The detailed structural analyses of the fluvial series are also supported by their textural features, which provides information on the source material and the transport conditions. The analysis of rounding and frosting of quartz grains of the sandy fraction $(0.5-0.8 \mathrm{~mm})$ according to Cailleux (1942) indicate that in the younger and in the youngest fluvial series (the sites of Nowe Dąbie, Wypaleniska and Zielonczyn), the high-energy fluvial environment (EL and EM/EL) grains dominate irrespectively of the lithofacial development of the deposits. The majority of the grains are of a very good rounding (on average $>15 \%$, but up to as much as $35 \%$ ). In the Pleistocene deposits the portion of the grains of that type generally does not exceed $5 \%$. This also refers to the underlying deposits (Woronko, 2001). Such a high percentage of the very well rounded grains of shiny and smooth surface, which developed in aqueous environment, was recorded in the contemporary alluvial sediments of the Vistula below the Włocławek Dam (unpublished). Undoubtedly, the high level of rounding resulted from the long-lasting and active presence in the fluvial environment where redeposition of the same alluvium took place a number of times. The morphological analysis of the quartz grains from the lower till in Zielonczyn showed identical spectrum of the grain types, for both the deposits of the younger and the youngest fluvial series at this site. This might have been conditioned by a cyclical exaration of the local base by the advancing ice sheet, and consequently, might have resulted in the development of a lowering (a depression) (Fig. 1). The investigated sites are located within the Torun Basin, which is surrounded by morainic plateaus sloping towards it. It can be concluded they are the northern extension of the exaration depression (Fig. 1) in the northern part of the Kuiavian Plateau, described by Molewski (2007). The results of the micromorphological tests of the quartz grains show that the dulled surface of the grains of this type contains a large number of V-shaped percussion cracks (Fig. 13). These cracks are an indicator of the advancing abrasion in the beach environment (Krinsley and Takahashi, 1962; Krinsley and Doornkamp, 1973) and the fluvial environment (Manickam and Barbaroux, 1987; Ostrowska, 2008; Woronko and Ostrowska, 2009). Based on the number of such microstructures, Margolis and Kennett (1971) classify aqueous environments and their energy: from fluvial with single cracks, to low-energy beach environment, and to high-energy aqueous environment where the number of cracks is significant. Moreover, Krinsley et al. (1964) say that the number of these cracks grows with the distance at which the grains are transported. On the other hand, however, the surfaces of grains of medium rounding (0.3-0.6 according to the Krumbein (1941) scale of rounding) and smooth and shiny surface (EM/EL), abrasion in the aqueous environment limited the number of $\mathrm{V}$-shaped percussion cracks on the edges (Fig. 14).

In numerous samples of the studied sand series there were grains with surfaces shaped by intensive chemical weathering that has left traces of in situ etching (OTH-
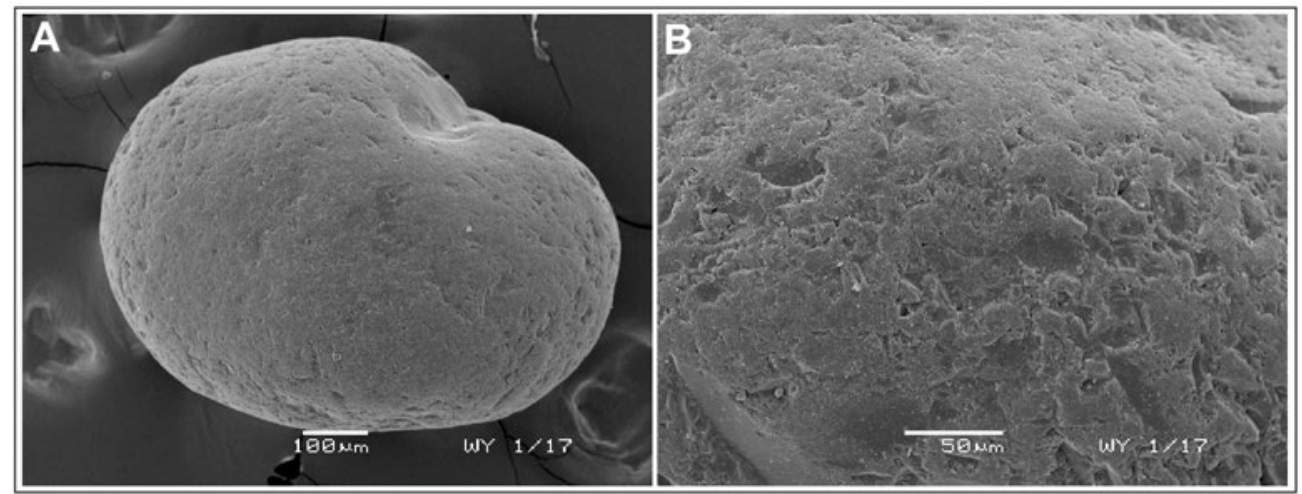

Fig. 13. A - very well rounded quartz grain with dulled surface represents high-energy aqueous environment (type EL) (Wypaleniska site), B - fragment of the quartz grain with dulled surface with high frequency of $V$-shaped percussion cracks, crescentic gouges and small conchoidal fractures (Wypaleniska site). 

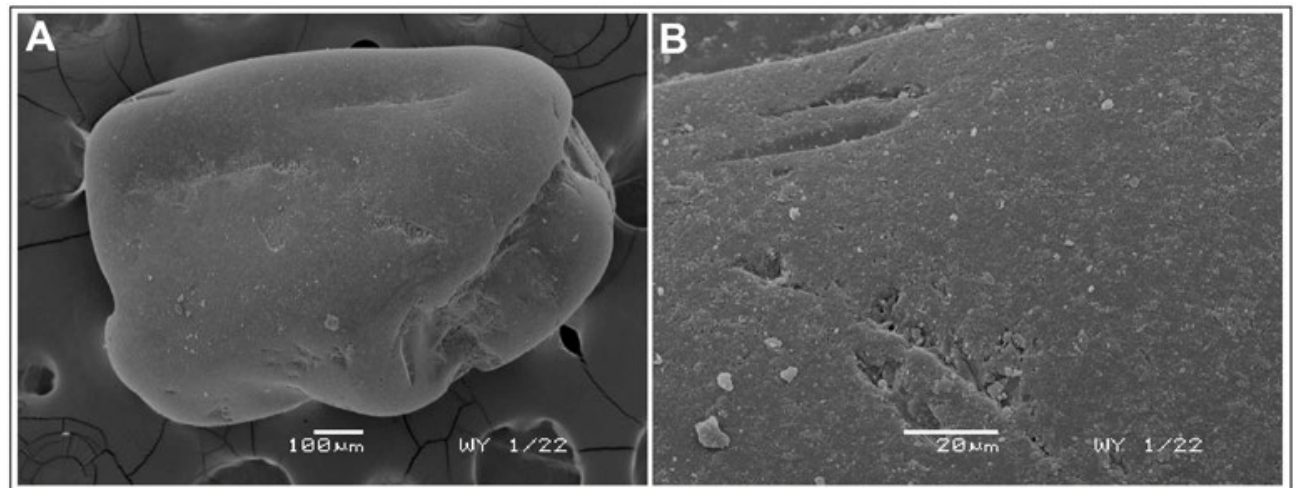

Fig. 14. A - well rounded quartz grain with dulled surface represents high-energy aqueous environment (type EM/EL) (Wypaleniska site), $B$ - fragment of the quartz grain dulled surface with low frequency of V-shaped percussion cracks (Wypaleniska site).

ER). The aeolian environment grains (RM and EM/RM) are represented only symbolically with a contribution not exceeding $7 \%$, and in most cases being just $1-2 \%$. The Vistula's alluvia below the Włocławek Dam do not contain grains which represent aeolian or weathering environment (of the OTHER type), and the cracked grains (C) make up less than $3 \%$ (unpublished). Additionally, except for the well-rounded grains, the analysed profiles contain totally angular or poorly rounded feldspars.

The results of the rounding and frosting analysis of the quartz grains seem to indicate that the younger and the youngest fluvial series, which come from the end of Middle Weichselian and the beginning of Late Weichselian (the sites of Nowe Dąbie, Wypaleniska and Zielonczyn), represent the alluvium from the rivers fed from two different sources. This idea is supported by the amount of the $\mathrm{V}$-shaped percussion cracks on the surfaces of the quartz grains; it is very large for most of the EL grains and low on the surfaces of the EM/E grains. In the first case, the source of the material might have been the alluvium of a warm river which "worked" its sediment a number of times, while in the second case these were mainly the Quaternary deposits. The river system, thus, developing during the two cycles of accumulation of the younger and the youngest fluvial series in the Torun Basin, might have been fed, on the one hand, by the older extraglacial deposits (a number of redepositional events of the same alluvium). On the other hand, these were also the deposits from the melting ice sheet. The aggradation of these two alluvial deposits was fast enough to keep the textural features of both sources materials. This is supported by the fact that the share of totally angular or poorly rounded feldspar is significant in the deposit. It can be assumed, thus, that at the end of Middle Weichselian and at the beginning of Late Weichselian the river systems of the ice marginal streamway (pradolina) character existed along the Torun Basin. Their evolution was stimulated by a cyclical advance or retreat of the ice sheet against the neotectonic movements (Weckwerth, 2007; 2010). Similarly high homogenization of the textural features of the deposits recorded in the analyzed deposits of the younger and the youngest fluvial series, as well as in the both levels of tills from the site of Zielonczyn, was found in the tills near Lusowo (10 km to the west of Poznań). They build the forms which were formed by the ice streams during the Last Glacial Maximum in the Wielkopolska Lowland (Morawska and Morawski, 2009). At the same time the Vistula Valley was also taken by an ice stream (Punkari, 1993; Boulton et al., 2001; Wysota et al., 2009), which might have been responsible for such a development of the deposits. The ice moved southwards along the existing river valleys, which resulted in enrichment of the tills in local deposits of the two youngest fluvial series, and the creation and renewing the exarative depression along the Lower Vistula Valley and the Torun Basin.

\section{CONCLUSIONS}

Interpretation of the OSL results is difficult due to the relatively large uncertainties associated with OSL dates and short time of sedimentation on the other hand. However, the results of the studies on the fluvial series in the Torun Basin and the mouth section of the Drwęca Valley enabled the authors to delimit three fluvial series of diverse age and the features of the depositional environment. The oldest of them (the oldest fluvial series) was found in the lower section of the Drwęca Valley and was deposited during the Saalian Glaciation by a low-energy sand-bed river with side-bars and migrating transverse bars. Its deposits might represent the transitional features of the fluvial deposition: from a meandering river of low sinuosity to a braided river. The water was flowing towards south-east.

During Middle Weichselian, i.e. by about 29 ka ago, the deposition of the younger fluvial series took place in the Torun Basin and the lower section of the Drwęca Valley. At that time a sand-bed braided river was flowing there. It contained large transverse bars. These were complex forms and created mid-channel areas of shallow water with secondary bars of almost five times smaller size (or two-dimensional dunes). Moreover, this river 
developed secondary channels of diverse depth as well as a floodplain dominated by the low-energy deposition of the suspended material accumulated when flood waters were going down. The river system included the main bed of the sand-bed braided river, as well as sinuous individual channels of a braided system opening into it.

Between about $27 \mathrm{ka}$ and $21 \mathrm{ka}$ ago, the river system included low sinuous channels with side-bars and low channel gradiend, which was later transformed in a braided river of the sandy bottom (increasing channel gradient) dominated by transverse bars in the central and southern part of the Torun Basin (youngest fluvial series, Zielonczyn formation). The water flow conditions were between the lower and the upper stage of the lower flow regime. With the change in the flow direction from the west to the north-west the dynamics of the water flow decreased.

The age of the younger and youngest fluvial series in the Torun Basin, separated by the till in Zielonczyn site (lower Zielonczyn till), indicates the first advance of the Scandinavian ice sheet during the Weichselian Glaciation into the Torun Basin took place about $28 \pm 4$ ka ago, although this thesis should be confirmed by the research in the other sites of North Poland. This approximate age of the lower Zielonczyn till formation, was estimated as the centre and width of the time range limited by the OSL dates obtained from the beneath (TO162: 28.5+3.4 ka) and above (TO158: 26.9-3.2 ka) sediment layers.

The source material for the two rivers within the Torun Basin, both during the Middle and the Late Weichselian, were possibly the deposits transported by the rivers flowing into the basin from the extraglacial zone in the south, as well as the deposits exarated by the ice sheet from the older river series and from the pre-quaternary basis from the north. It can be assumed, thus, that at the end of Middle Weichselian and at the beginning of Late Weichselian the river systems of the ice marginal streamway (pradolina) character existed along the Torun Basin.

\section{ACKNOWLEDGEMENT}

The research project has been financially supported by the grant No. N N306 353833 obtained from the Ministry of Science and Higher Education. Ewa Smolska and an anonymous reviewer are acknowledged for their professional and careful reviewing of the manuscript.

\section{REFERNCES}

Bøtter-Jensen L and Duller GAT, 1992. A new system for measuring optically stimulated luminescence from quartz samples. Nuclear Tracks and Radiation Measurements 20(4): 549-553, DOI 10.1016/1359-0189(92)90003-E.

Boulton GS, Dongelmans P, Punkari M and Broadgate M, 2001. Palaeoglaciology of an ice sheet through a glacial cycle: the European ice sheet through the Weichselian. Quaternary Science Reviews 20(4): 591-625, DOI 10.1016/S0277-3791(00)00160-8.
Cailleux A, 1942. Les actiones éoliennes périglaciaires en Europe. Mémoire de la société Géologique de France 41: 176pp (in French).

Cant DJ and Walker RG, 1976. Development of a braided-fluvial facies model for the Devonian Battery Point Sandstone, Quebec. Canadian Journal of Earth Sciences 13: 102-119, DOI 10.1139/e76-010

Cant DJ and Walker RG, 1978. Fluvial processes and facies sequences in the sandy braided South Saskatchewan River, Canada. Sedimentology 25(5): 625-648, DOI 10.1111/j.1365-3091.1978.tb00323.x.

Collinson J, Mountney N and Thompson D, 2006. Sedimentary structures, 3. Terra Publishing Harpenden, England: 304pp.

Duller GAT, 2007. Assessing the error on equivalent dose estimates derived from single aliquot regenerative dose measurements. $\mathrm{An}$ cient TL 25: 15-24.

Folk RL and Ward WC, 1957. Brazos River bar: a study in the significance of grain size parameters. Journal of Sedimentary Petrology 27(1): 3-26.

Goździk J, 1980. Zastosowanie morfometrii i graniformametrii do badań osadów w kopalni węgla brunatnego Bełchatów. Studia Regionalne IV (IX). PWN Warszawa-Łódź: 101-114 (in Polish).

Houmark-Nielsen M, 2007. Extent and age of Middle and Late Pleistocene glaciations and periglacial episodes in southern Jylland, Denmark. Bulletin of the Geological Society of Denmark 55: 9-35.

Houmark-Nielsen M, 2010. Extent, age and dynamics of Marine Isotope Stage 3 glaciations in the southwestern Baltic Basin. Boreas 39(2): 343-359, DOI 10.1111/j.1502-3885.2009.00136.x.

Houmark-Nielsen M and Kjær KH, 2003. Southwest Scandinavia 40-15 ka BP: Plaleogeography and environmental change. Journal of Quaternary Science 18(8): 769-786, DOI 10.1002/jqs.802.

Krinsley DH and Doornkamp JC, 1973. Atlas of quartz sand surface textures. Cambrige Univ. Press.

Krinsley DH and Takahashi T, 1962. The surface textures of sand grains: an application of electron microscopy: glaciation. Science 138(3546): 1262-1264, DOI 10.1126/science.138.3546.1262.

Krinsley DH, Takahashi T, Silberman ML and Newman WS, 1964. Transportation of sand grains along the Atlantic shore Long Island, New York: An application of electron microscopy. Marine Geology 2: 100-120, DOI 10.1016/0025-3227(64)90029-5.

Krumbein WC, 1941. Measurement and geological significance of shape and roundness of sedimentary particles. Journal of Sedimentary Petrology 11: 64-72, DOI 10.1306/D42690F3-2B26-11D7$8648000102 \mathrm{C} 1865 \mathrm{D}$

Latałowa M, 2003. Późny Vistulian (Late Vistulian). In: DybowaJachowicz S and Sadowska A, eds, Palinologia. Wyd. PAN Instytut Botaniki, Kraków: 266-273 (in Polish).

Makowska A, 1979. Interglacjał eemski w Dolinie Dolnej Wisły (Eemian interglacial In the Valley of Lower Vistula River). Studia Geologica Polonica 63: 90pp (in Polish).

Manickam S and Barbaroux L, 1987. Variations in the surface texture of suspended quartz grains in the Loire river: An SEM study. Sedimentology 34(3): 495-510, DOI $\quad 10.1111 /$ j.13653091.1987.tb00581.x.

Margolis S and Kennett JP, 1971. Cenozoic, paleoglacial history of Antarctica, recrded in subarctic deep-sea cores. American Journal of Science 271: 1-36, DOI 10.2475/ajs.271.1.1.

Marks L, 2010. Timing of the Late Vistulian (Weichselian) glacial phases in Poland. Quaternary Science Reviews (in press), DOI 10.1016/j.quascirev.2010.08.008.

Marren PM, 2005. Magnitude and frequency in proglacial rivers: a geomorphological and sedimentological perspective. EarthScience Reviews 70(3-4): 203-251, DOI 10.1016/j.earscirev.2004.12.002

Miall AD, 1978. Lithofacies types and vertical profile models in braided rivers: A summary. In: Miall AD, ed., Fluvial Sedimentology. Canadian Society of Petroleum Geologists, Memoir 5: 597-604.

Miall AD, 1985. Architectural-element analysis: a new metod of facies analysis applied to fluvial deposits. Earth-Science Reviews 22(4): 261-308, DOI 10.1016/0012-8252(85)90001-7.

Molewski P, 2007. Neotektoniczne i glacidynamiczne uwarunkowania wykształcenia plejstocenu Wysoczyzny Kujawskiej (Neotectonic and glaciodynamic conditions for the formation of the Pleistocene 
of the Kujawy Moraine Plateau). Wydawnictwo Naukowe Uniwersytetu Mikołaja Kopernika, Toruń: 140pp (in Polish).

Morawska M and Morawski M, 2009. Formy po strumieniach lodowych w Polsce Zachodniej i Północno-Zachodniej - identyfikacja w rzeźbie. In: Kostrzewski A, ed., Geneza, litologia, stratygrafia utworów czwartorzędowych (Genesis, lithology and stratigraphy of Quaternary deposits). SGP, UAM Poznań, t. V (in Polish).

Murray AS and Wintle AG, 2000. Luminescence dating of quartz using an improved single-aliquot regenerative-dose protocol. Radiation Measurements 32(1): 57-73, DOI 10.1016/S1350-4487(99)00253$\mathrm{X}$.

Mycielska-Dowgiałło E, 2007. Metody badań cech teksturalnych osadów klastycznych i wartość interpretacyjna wyników (Methods of researches of the textural features of clastic deposits and their interpretation value). In: Mycielska-Dowgiałło E and Rutkowski J, eds., Badania cech teksturalnych osadów czwartorzędowych $i$ wybrane metody oznaczania ich wieku. WSWPR, Warszawa: 95180 (in Polish).

Mycielska-Dowgiałło E and Woronko B, 1998. Analiza obtoczenia i zmatowienia powierzchni ziarn kwarcowych frakcji piaszczystej i jej wartość interpretacyjna (Rounding and frosting analysis of quarto grains of Sand fraction, and its interpretative value). Przegląd Geologiczny 46: 1275-1281 (in Polish).

Nanson GC and Knighton AD, 1996. Anabranching rivers: their cause, character and classification. Earth Surface Processes and Landforms 21(3): 217-239, DOI 10.1002/(SICI)10969837(199603)21:3<217::AID-ESP611>3.0.CO;2-U.

Oczkowski HL and Przegiętka K, 1998. Partial Matrix Doses for Thermoluminescence Dating. Physica Scripta 58(5): 534-537, DOI 10.1088/0031-8949/58/5/019.

Oczkowski HL, Przegiętka K, Lankauf KR and Szmańda JB, 2000. Gamma Spectrometry in Thermoluminescence Dating. Geochronometria 18: 63-68.

Olsen H, 1988. The architecture of a sandy braided-meandering river system: an example from the Lower Triassic Solling Formation (M. Buntsandstein) in W-Germany. Geologische Rundschau 77(3): 797-814, DOI 10.1007/BF01830186.

Ostrowska M, 2008. Wpływ środowiska fluwialnego na charakter powierzchni ziaren kwarcowych na przykładzie aluwiów rzeki Nurzec. Master's thesis. WGSR UW. Warszawa (in Polish).

Punkari M, 1993. Modelling of the dynamics of the Scandinavian ice sheet using remote sensing and GIS methods. In: Aber JS, ed., Glaciotectonics and mapping glacial deposits. Canadian Plains Research Center. University of Regina: 232-250.

Salamon T and Zieliński T, 2010. Unusual development of sandur sedimentary succession, an example from the Pleistocene of S Poland. Geologos 16(2): 83-99, DOI 10.2478/v10118-009-0007-9.

Smith ND, 1970. The braided stream depositional environment: comparison of the Platte River with some Silurian clastic rocks, NorthCentral Appalachians. Geological Society of America Bulletin 81(10): 2993-3014, $\quad$ DOI $10.1130 / 0016-$ 7606(1970)81[2993:TBSDEC]2.0.CO;2.

Schwartz DE, 1978. Hydrology and current orientation analysis of braided-to-meandering transition: the Red River in Oklahoma and Texas, U.S.A. In: Miall AD, ed., Fluvial sedimentology. Canadian Society of Petroleum Geologists: 231-255.

Tunbridge IP, 1981. Sandy high-energy flood sedimentation some criteria for recognition, with an example from the Devonian of SW England. Sedimentary Geology 28(2): 79-95, DOI 10.1016/00370738(81)90058-0.

Tunbridge IP, 1984. Facies model for a sandy ephemeral stream and clay playa complex: the Middle Devonian Trentishoe Formation of North Devon, UK. Sedimentology 31(5): 697-715, DOI 10.1111/j.1365-3091.1984.tb01231.x.

Weckwerth P, 2004. Morfogeneza wybranych obszarów Kotliny Toruńskiej a problem jej roli w układzie hydrograficznym podczas górnego plenivistulianu (Morphogenesis selected areas of the Torun Basin and their part in hydrographic network during upper plenivistulian). $\mathrm{PhD}$ thesis, UMK Torun (in Polish).

Weckwerth P, 2007. Późnovistuliański rozwój sieci rzecznej w rejonie Kotliny Toruńskiej na tle struktur starszego podłoża (The river network development in the Torun Basin in the Late Weichselian on the basis of older geological structures). In: Florek W, ed., Stupskie Prace Geograficzne 4: 143-156 (in Polish).

Weckwerth P, 2009a. Srodowisko depozycji fluwialnej w stadiale głównym zlodowacenia Wisły - stanowisko Nowe Dąbie, południowo-zachodnia część Kotliny Toruńskiej (Fluvial depositional envinronment in the Main Stadial of Weichselian Glaciation. In: Pisarska-Jamroży $\mathrm{M}$ and Babiński Z, eds., Plejstoceńskie środowiska sedymentacyjne Pojezierza Pomorskiego, Wydawnictwo UKW, Bydgoszcz: 90-99 (in Polish).

Weckwerth P, 2009b. Warunki depozycji osadów plenivistuliańskiej rzeki roztokowej w Kotlinie Toruńskiej (Depositional conditions of Plenivistulian breided river in the Torun Basin). In: Żarski M and Lisicki S, eds., XVI Konferencja Stratygrafia Plejstocenu Polski, Strefa marginalna ladolodu zlodowacenia warty i pojezierza plejstoceńskie na poludniowym Podlasiu: 135-138 (in Polish).

Weckwerth P, 2010. Evolution of the Torun Basin in the Late Weichselian. Landform Analysis 14: 57-84.

Weckwerth P, Przegiętka KR and Chruścińska A, 2011. The OSL Age inversion of sand-bed braided river deposits in the Torun Basin (Poland), submitted to Quaternary Geochronology.

Wintle AG and Murray AS, 2006. A review of quartz optically stimulated luminescence characteristics and their relevance in singlealiquot regeneration dating protocols. Radiation Measurements 41(4): 369-391, DOI 10.1016/j.radmeas.2005.11.001.

Włodek M, 1980. Młodszy plejstocen w rejonie Nakła nad Notecią(Younger Pleistocene in the area of Nakło on the Noteć). Przeglad Geologiczny 8: 453-456 (in Polish).

Woronko B, 2001. Znaczenie analizy obtoczenia i zmatowienia powierzchni ziarn kwarcowych frakcji piaszczystej w interpretacji genetycznej osadów czwartorzędowych. In: Mycielska-Dowgiałło E, ed., Eolizacja osadów jako wskaźnik stratygraficzny Czwartorzędu. Pracownia Sedymentologiczna, WGiSR: 33-38 (in Polish).

Woronko B and Ostrowska M, 2009. Wpływ środowiska fluwialnego na charakter powierzchni ziarn kwarcowych - dyskusja. In: Kostrzewski A and Paluszkiewicz R, eds, Geneza, litologia i stratygrafia utworów czwartorzędowych (Genesis, lithology and stratigraphy of Quaternary deposits) V: 605-622 (in Polish).

Wysota W, 2002. Stratygrafia i środowiska sedymentacji zlodowacenia wisty w poludniowej części dolnego Powiśla (Stratigraphy and sedimentary environments of the Vistulian (Weichselian) glaciation in the southern part of the Lower Vistula region, middle-north Poland). Wydawnictwo UMK: 144pp (in Polish).

Wysota W, Lankauf KR, Molewski P and Szmańda J, 1996. Sedymentologia interstadialnej serii rzecznej (Rzęczkowo) zlodowacenia Wisły (Vistulian) odsłoniętej w SW krawędzi Wysoczyzny Chełmińskiej (Sedimentology of the interstadial fluvial series (Rzęczkowo) of the Vistulian glaciation expose in the SW margin of the Chełmno Moraine Plateau). Acta Universitatis Nicolai Copernic, Geografia 28: 39-63.

Wysota W, Molewski P and Sokołowski RJ, 2009. Record of the Vistula ice lobe advances in the Late Weichselian glacial sequence in north-central Poland. Quaternary International 207(1-2): 26-41, DOI 10.1016/j.quaint.2008.12.015.

Zieliński T, 1992. Proglacial valley facies of the Silesian Upland genetic factors and their sedimentological effects. Geologica Sudetica 26(1-2): 83-118.

Zieliński T, 1993. Sandry Polski północno-wschodniej - osady i warunki sedymentacji (Outwash plains of NE Poland - sediments and deposits processes). Prace Naukowe Uniwersytetu Ślaskiego 1398: 97pp (in Polish).

Zieliński T, 1998. Litofacjalna identyfikacja osadów rzecznych (Lithofacial identification of alluvial sediments). In. MycielskaDowgiałło E, ed., Struktury sedymentacyjne i postsedymentacyjne $w$ osadach czwartorzędowych $i$ ich wartość interpretacyjna (Sedimentological and postsedimentological structures in Quaternary sediments and their value for interpretation) Wydział Geografii I Studiów Regionalnych Uniwersytetu Warszawskiego, Warszawa: 195-257. 